\title{
Estimation of combining ability analysis in tomato (Solanum lycopersicum L.) for yield, nutritional and processing quality improvement
}

\author{
Chandan Kumar and S. P. Singh* \\ ICAR-Central Arid Zone Research Institute, Krishi Vigyan Kendra, Pali-Marwar -306401 (Rajasthan), INDIA \\ *Department of Horticulture, Institute of Agriculture Science, Banaras Hindu University, Varanasi - 221005 (U.P.), \\ INDIA \\ *Corresponding author. Email: chandankumarveg.sc@gmail.com \\ Received: April 15, 2016; Revised received: May 18, 2017; Accepted: September 18, 2017
}

\begin{abstract}
Combining ability for yield and nutritional quality traits in tomato were studied by involving 28 cross combinations obtained from crossing 8 diverse lines in diallel mating fashion. Based on GCA effects of parents, the varieties Pant T-3, Arka Alok and Sel-7 were good general combiners for most of the traits under study. The crosses viz., Pant T-3 x H-24 (1.052\%), Arka Meghali x Punjab Chhuhara (0.768\%) and H-88-78-1 x Azad T-5 (0.768\%) were found to be high positive specific combining ability effect for yield per plant. For quality traits, the crosses Arka Meghali x Punjab Chhuhara and H-24 x Sel-7 were also superior specific combiner for number of seeds per fruit and ascorbic acid, while cross Punjab Chhuhara $\times$ H-88-78-1 was superior specific combiner for number of seeds per fruit $(24.165 \%)$, yield per plant $(0.677 \%)$ and titrable acidity $(0.183 \%)$. These elite hybrids may be tested for yield and other quality traits under different agro-climatic conditions for commercial exploitation of hybrid vigour.
\end{abstract}

Keywords: Combining ability, Hybrids, Quality, Tomato, Yield

\section{INTRODUCTION}

Tomato (Lycopersicum esculentum L.) is one of the most important vegetable crops grown throughout the world because of its wider adaptability, high yielding potential and suitability for variety of uses in fresh as well as processed food industries (Kumar and Singh, 2016a). The fruits are available year round and eaten raw or cooked. Tomato in large quantities is used to produce soup, juice, ketchup, puree, paste and powder; it supplies ascorbic acid and adds variety of colours and flavors to the food. All fruit quality attributes were expressions of genotypic and environmental effect of interactions. Hence quality attributes have to be considered together for future genetic improvement of tomato quality. Total soluble solids (TSS) and ascorbic acid have been recognized as the most desirable attributes in tomato for processing industry. The increase of $1 \%$ TSS in fruits results to increase $20 \%$ recovery of processed products (Kumar and Singh, 2016b).

High ascorbic acid content in addition to improving the nutrition also helps in the better retention of natural colour and flavour of the tomato products. The red pigment in tomato (lycopene) is now being considered as the "world's most powerful natural antioxidant". Therefore, tomato is one of the most important 'protective foods' because of its special nutritive value. Characters like number of locules per fruit and pericarp thickness are the important parameters contributing towards shelf life besides biochemical changes
(Dagade, et al. 2015).

Efforts are being made to increase its productivity by developing superior varieties. Plant breeders have extensively explored and utilized heterosis to boost yield and quality levels in several cross-pollinated crops in the recent past. Tomato belongs to the large and diverse Solanaceae family also called Nightshades which includes more than three thousand species Exploring natural diversity as a source of novel alleles to improve the productivity, quality and nutritional value of the crop is the base line of any breeding programme (Fernie et al. 2006).

Although tomato is a self pollinated crop, heterosis is being commercially exploited on large scale. The combining ability analysis helps in diagnosing or identifying additive or non-additive gene action would in turn lead a breeder to select desirable parents or cross combinations that would be exploited for crop improvement. A knowledge of general combining ability (GCA) and specific combining ability (SCA) helps in choice of parents or hybrids and the nature of gene action acts as bases of choosing effective breeding methods (Kumar and Singh, 2016b). The present investigation was undertaken to identify parental combination that are likely to produce superior hybrids having highest yield and quality.

\section{MATERIALS AND METHODS}

The present study was conducted at Horticulture Re- 
search Farm, Institute of Agricultural Sciences, Banaras Hindu University, Varanasi (U.P.), India during Rabi season of 2012 and 2013. The soil of experimental field was alluvial type of soil with average fertility level and $\mathrm{pH}$ in the range of 6.6 to 7.4. The experimental materials was procured from Indian Institute of Vegetable Research, Varanasi (India) followed by selfing for maintenance. Eight genetically diverse lines (Arka Meghali, Pant T-3, Punjab Chhuhara, H-88 -78-1, Arka Alok, Azad T-5, H-24 (Hisar Anmol), Sel7 (Hisar Arun)) were crossed in diallel mating design during rabi 2012. The resultant $28 \mathrm{~F}_{1}$ 's were evaluated along with their parents was during rabi 2013 in randomized block design which was replicated thrice. Each entry was grown in one row of 10 plants in each by adopting inter row spacing of $60 \mathrm{~cm}$ and intra row spacing of $45 \mathrm{~cm}$. The observations were recorded on five randomly selected plants for viz., number of fruit per plant, number of locules per fruit, pericarp thickness $(\mathrm{cm})$, number of seed per fruit, yield per plant (Kg.), total soluble solids ( ${ }^{\circ}$ Brix), ascorbic acid (mg/100g fw), acidity as ACA (\%), Lycopene content. For estimation of quality traits, ripe fruits were selected randomly. Total soluble solids was estimated by using hand refractometer, ascorbic acid and lycopene content was estimated according to procedure given by Ranganna (1986), titrable acidity will be measure based on the titration of tomato acid mainly citric acid, by an alkaline solution. Data collected during the two growing seasons for above characters were pooled and analysis of variance and combining ability analysis were done as according to Singh and Chaudhary (1979) based on Griffing's (1956) fixed effect model using the following formula:

$$
X_{i j k}=\mu+g_{i}+g_{j}+S_{i j}+e_{i j k}
$$

Where, $\mu=$ General mean, $g_{i}=$ GCA effect of $i^{\text {th }}$ line, $i$ $=1,2, \ldots \ldots \ldots . \mathrm{i}$ (Number of lines), $g_{j}=$ GCA effect of $j^{\text {th }}$ tester, $\mathrm{j}=1,2, \ldots \ldots \ldots \mathrm{j}$ (Number of testers), $\mathrm{S}_{\mathrm{ij}}=\mathrm{SCA}$ effect of the $\mathrm{ij}^{\text {th }}$ combination, $\mathrm{e}_{\mathrm{ijk}}=$ Error associated with the observation, $\mathrm{k}=1,2, \ldots \ldots \ldots . \mathrm{r}$ (Number of replications).

\section{RESULTS AND DISCUSSION}

Analysis of variance (Table 1) for combining ability revealed that the variance due to genotypes effect was highly significant $(@ \mathrm{P} \leq 0.01)$ for all characters. Mean sum of square due to parent were highly significant for all traits indicating genetic diversity among the parent (GCA) except lycopene content, thus highest contribution by these characters towards combining ability. Highly significant variation due to GCA and SCA except TSS indicates the importance of additive as well as non-additive types of gene action in inheritance of these characters. These findings are in close agreement with Hannan et al. (2007a), Kumar et al. (2013) and Shankar et al. (2013) in tomato crop. They also found that highly significant variation due to GCA as well as SCA indicated the importance of additive as well as non-additive types of gene action of inheritance for all the traits except some traits.

The predictability ratio of GCA / SCA variance was less than 1 for number of seeds per fruit, fruit yield per plant and lycopene content showing preponderance of non-additive gene effects. Parents showing nonadditive gene action can be utilised in development of hybrids with desirable traits. while it was more than 1 for number of fruit per plant, number of locules per fruit, pericarp thickness, TSS, ascorbic acid and acidity as ACA indicating predominance of additive gene effect.

Effect of GCA: Nature and magnitude of combining ability effects provide guideline in identifying the better parents and their utilization. Among parents (Table 2), Pant T-3, Arka Alok and Sel-7 were found good general combiner for most of the traits under study. Sel -7 showed desirable GCA effects for number of fruit per plant, number of locules per fruit, number of seeds per fruit and ascorbic acid as it had GCA values of $6.040,0.175,3.885$ and 1.452 , respectively. The parent Punjab chhuhara was attractive for pericarp thickness and TSS with GCA values of 0.045 and 0.342 , respectively. Variety Arka Alok had higher GCA effect for number of seeds per fruit and fruit yield per plant with GCA value of 3.337 and 0.222 , respectively. Parent Pant T-3 was favourable for number of fruit per plant, ascorbic acid and acidity, GCA effect of 2.728, 1.988 and 0.130 , respectively. However, none of the parent was best general combiner for all the traits indicating differences in genetic variability for different charac-

Table 1. Analysis of variance (ANOVA) for combing ability for different characters.

\begin{tabular}{lllllllllll}
\hline $\begin{array}{l}\text { Source } \\
\text { of vari- } \\
\text { ation }\end{array}$ & $\begin{array}{lllll}\text { d.f } \\
\text { Number } \\
\text { of fruits } \\
\text { per plant }\end{array}$ & $\begin{array}{l}\text { Number } \\
\text { of locules } \\
\text { per fruit }\end{array}$ & $\begin{array}{l}\text { Pericarp } \\
\text { thick- } \\
\text { ness } \\
\text { (cm) }\end{array}$ & $\begin{array}{l}\text { Number } \\
\text { of seeds } \\
\text { per fruit }\end{array}$ & $\begin{array}{l}\text { Yield } \\
\text { per } \\
\text { plant } \\
\text { (Kg.) }\end{array}$ & $\begin{array}{l}\text { TSS } \\
\left({ }^{\circ} \text { Brix) }\right.\end{array}$ & $\begin{array}{l}\text { Ascorbic } \\
\text { acid } \\
\text { (mg/100g } \\
\text { fresh } \\
\text { weight) }\end{array}$ & $\begin{array}{l}\text { Acidity as } \\
\text { anhydrous } \\
\text { citric acid } \\
(\%)\end{array}$ & $\begin{array}{l}\text { Lyco- } \\
\text { pene } \\
\text { con- } \\
\text { tent }\end{array}$ \\
\hline GCA & 7 & $10.61^{* *}$ & $0.392^{* *}$ & $0.028^{* *}$ & $465.07^{* *}$ & $1.09^{* *}$ & $0.92^{* *}$ & $62.34^{* *}$ & $0.111^{* *}$ & $0.014^{*}$ \\
SCA & 28 & $78.16^{* *}$ & $0.207^{* *}$ & $0.006^{*}$ & $649.84^{* *}$ & $1.11^{* *}$ & 0.274 & $10.19^{* *}$ & $0.021^{* *}$ & $0.018^{* *}$ \\
EROR & 70 & 11.087 & 0.075 & 0.003 & 13.251 & 0.042 & 0.257 & 3.33 & 0.007 & 0.006 \\
GCA/SCA & 3.97 & 1.89 & 4.67 & 0.72 & 0.99 & 3.36 & 6.11 & 5.29 & 0.78 \\
ratio & & & & & & & & & & \\
\hline
\end{tabular}

*, ** significant at $5 \%$ and $1 \%$ level, respectively 
Chandan Kumar and S. P. Singh / J. Appl. \& Nat. Sci. 9 (4): 2021 -2025 (2017)

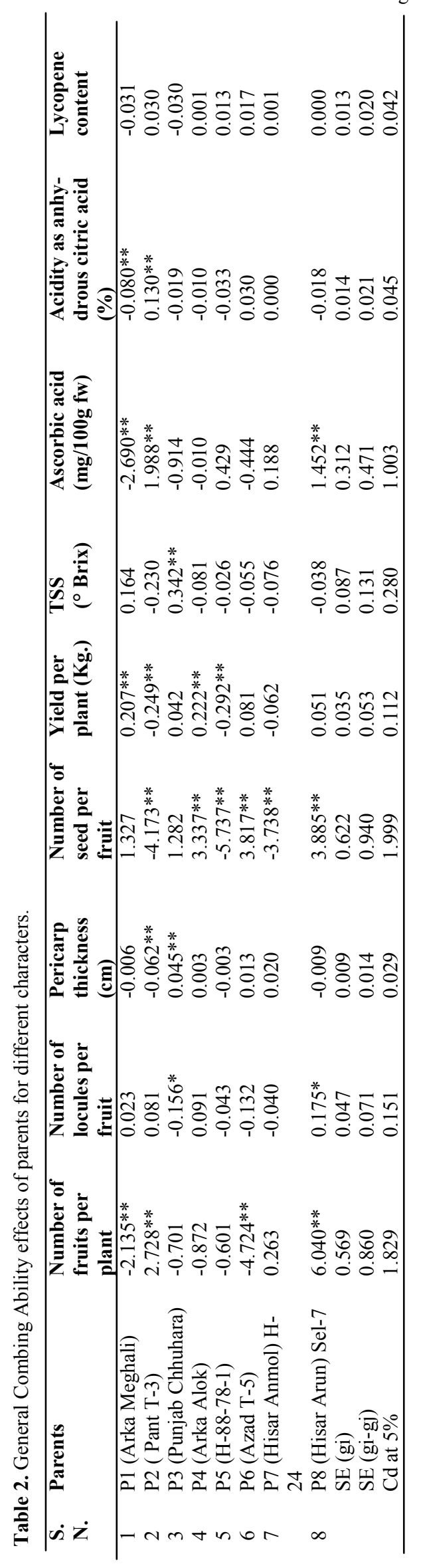

ters among the parents. These observations revealed that these quality traits with yield could be improved by using these parents in hybrid breeding programme for accumulation of favourable genes.

Effect of SCA: The SCA effects signify the role of non-additive gene action in the expression of a trait and this is due to dominance variance and epistatic variances. It shows the highly specific combining abilities leading to the higher performance of some specific cross combinations and that is the reason why it is related to a particular cross. High SCA effects may arise not only in crosses involving high combiners but also in those involving low combiners. The details of SCA analysis of 28 crosses (Table 3) their per se performance are being furnished below. This result getting support from the finding of Hannan et al. (2007b), Kumar et al. (2013), Pedapati et al. (2013) and Dagade et al (2015) in tomato crop.

For number of fruits per plant the highest significant positive value (8.823) for SCA effect was recorded in H-24 x Sel-7 followed by Punjab Chhuhara x Sel-7 (7.137), Pant T-3 x Azad T-5 (6.346) and Pant T-3 x Sel-7 (6.262). In case of nnumber of locules per fruit trait, the significant positive SCA effects obtained in Pant T-3 x Azad T-5 (0.545) cross followed by Pant T3 x Punjab Chhuhara (0.398) and H-88-78-1 x Azad T5 (0.365). Hybrid H-88-78-1x Arka Alok (0.066) was recorded significant positive SCA effect for pericarp thickness trait whereas, hybrids Arka Meghali x Punjab Chhuhara (-0.080), Punjab Chhuhara x H-88-78-1 (-0.075) and H-88-78-1 x Azad T-5 (0.056) showed significant negative SCA effects.

Maximum crosses are highly significant for number of seed per fruit character, 22 crosses out of 28 are positive and negative significant. The highest desirable positive significant SCA effect value was recorded in the cross Arka Meghali x Punjab Chhuhara (28.685) followed by Punjab Chhuhara x H-88-78-1 (24.165) and H-88-78-1 x Azad T-5 (20.920). For yield per plant SCA effects ranged between -0.222 in Pant T-3 $x$ H-88-78-1 and 1.052 in Pant T-3 x H-24. 18 out of 28 crosses were found positive and negative significant.

For TSS trait none of the cross combinations were significant either positive or negative. The best five specific combinations for ascorbic acid Viz., H-88-78-1 x Azad T-5 (4.453), H-88-78-1 x H-24 (2.911), Arka Meghali x Punjab Chhuhara (2.166), Pant T-3 x Punjab Chhuhara (2.025) and H-24 x Sel-7 (1.986). Whereas, the crosses Punjab Chhuhara x H-88-78-1 (0.183), Arka Meghali x Arka Alok (0.102) and Azad T-5 x Sel -7 (0.088) was noticed highest significant positive SCA effect for acidity as ACA. Three crosses expressed positive SCA effects viz. Arka Alok x Azad T5 (0.149), Pant T-3 x H-88-78-1 (0.125) and H-88-781x Arka Alok (0.102) for lycopene content. The results of combining ability effects suggested that both additive and non-additive gene effects were important in 
Chandan Kumar and S. P. Singh / J. Appl. \& Nat. Sci. 9 (4): 2021 -2025 (2017)

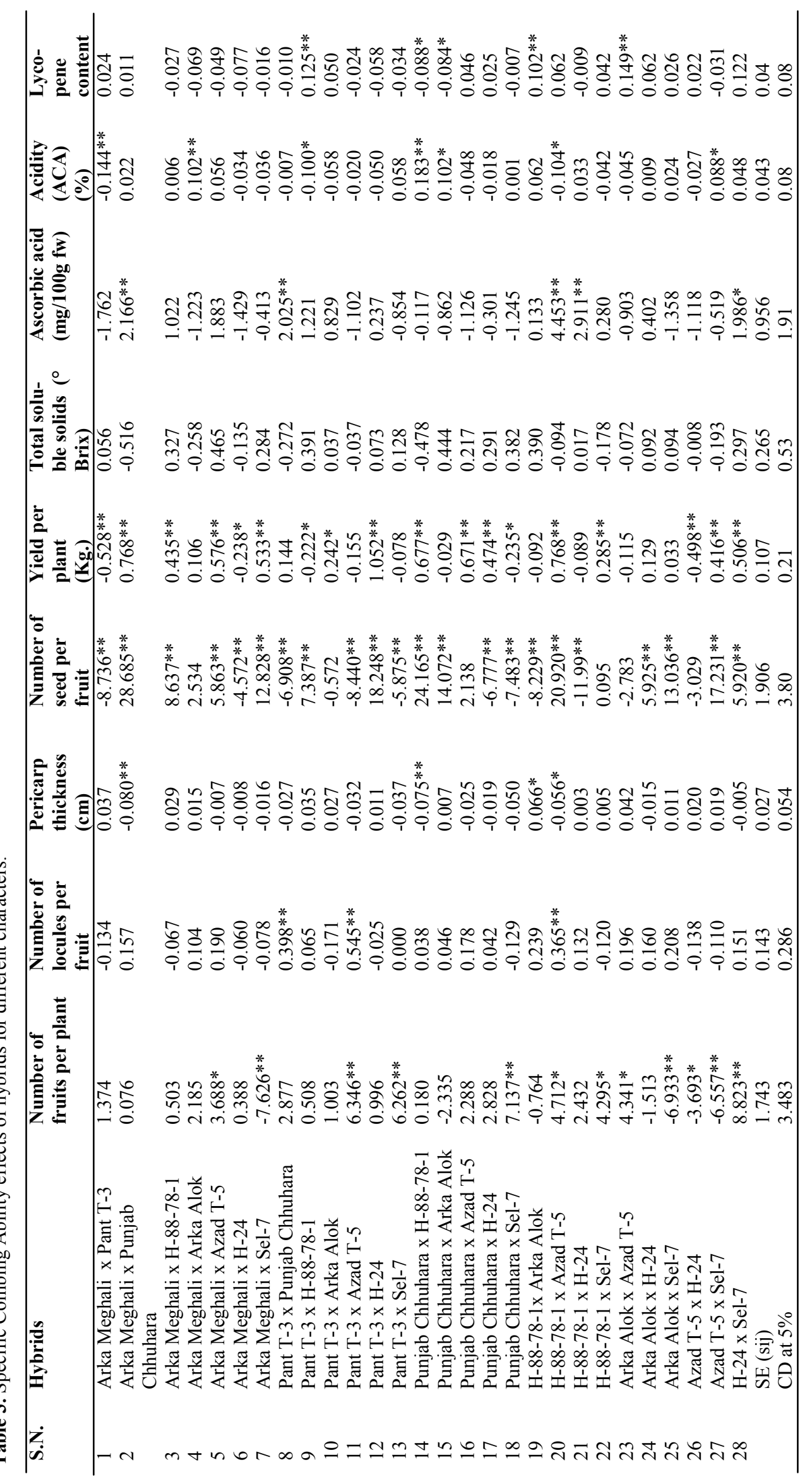


controlling the expression of all the studied characters. Therefore, $F_{1}$ hybrids may perform better, in one or more aspects, than either of their parents of commercial cultivars.

Normally SCA effects do not contribute much to the improvement of self-pollinated crops. However, the crosses showing desirable specific, along with good general, combining ability could be utilised in breeding programmes. Such programmes would be more effective if the 2 of the parents are a good combiner and the other one is a poor combiner. In such a situation, they are expected to produce desirable transgressive segregates if the additive genetic system in the good combiner and complementary epistatic effects present in the cross acts in the same direction so as to maximise desirable plant attributes (Salimath and Bahl, 1985). In our study Pant T-3, Arka Alok and Sel-7 were found good general combiner for most of the traits and rest of others is a poor combiner.

\section{ACKNOWLEDGEMENTS}

I proffer my sincere thanks to Indian Institute of Vegetable Research (IIVR), Varanasi for provide me genetically diverse lines and U.G.C. for providing fellowship (R/Dev./2012-13/3729) during course of investigation.

\section{REFERENCES}

Dagade, S.B., Barad, A.V and Dhaduk, L.K. (2015). Studies on Hybrid Vigour in $\mathrm{F}_{1}$ and Its Retention in $\mathrm{F}_{2}$ for Fruit Firmness and Related Traits in Tomato. Intl. J. Applied Bio. and Pharmaceutical Tech., 6(1): 193-198.

Fernie, A.R., Tadmor, Y. and Zamir, D. (2006). Natural genetic variation for improving crop quality. Current Opinion in Plant Biotechnology, 9: 196-202.

Griffing's, B. (1956). Concept of general and specific combining ability in relation to diallel crossing system. Australian J. of Biological Sciences, 9: 463-93.
Hannan, M.M., Biswas, M.K., Ahmed, M.B., Hossain, M. and Islam, R. (2007a). Combining Ability Analysis of Yield and Yield Components in Tomato (Lycopersicum esculentum Mill.). Turk. J. Bot. 31: 559-563.

Hannan. M.M., Ahmed, M.B., Razvy, M.A., Karim, R., Khatum, M., Hayder, A., Hussain, M. and Roy, U.K. (2007b). Heterosis and correlation of yield and yield components in tomato. Am-Eurasian J. Sci. Res. 2(2): 46-150.

Kumar, C. and Singh, S.P. (2016b). Analysis of Combining Ability to recognize superior $F_{1}$ Hybrids in Tomato (Lycopersicum esculentum L.) for Yield and its contributing traits. The Bioscan 11(2): 949-952.

Kumar, C. and Singh, S.P. (2016a). Heterosis and inbreeding depression to identify superior F1 hybrids in tomato (Solanum lycopersicum L.) for the yield and its contributing traits. Journal of Applied and Natural Sci. 8(1): 290-296.

Kumar, R., Srivastava, K., Singh, N.P., Vasistha, N.K., Singh, R.K. and Singh, M.K. (2013). Combining ability analysis for yield and quality traits in tomato (Solanum lycopersicum L.). J. Agri Sci., 5(2): 213-18.

Pedapati, A., Reddy, R.V.K.S., Babu, D., Kumar, S. and Sunil, N. (2013). Combining ability analysis for yield and physiological drought related traits in tomato (Solanum lycopersicum 1.) under moistures stress. The Bioscan 8(4): 1537-1544.

Ranganna, S. (1986) Handbook of Analysis and quality Control for Fruit and Vegtable products, Tata McGraw-Hill Education pp 92-95.

Salimath, P.M. and Bahl, P.N. (1985). Heterosis and combining ability for earliness in chickpea (Cicer arietinum L.). Indian J Genet 45: 97-100.

Shankar, A., Reddy, R.V.S.K., Sujatha, M. and Pratap, M. (2013). Combining Ability Analysis to Identify Superior $\mathrm{F}_{1}$ Hybrids for Yield and Quality Improvement in Tomato (Solanum lycopersicum L.). Agrotechnology 2: 3.

Singh, R.K. and Chaudhary, B.D. (1979). Biometrical methods in quantitative genetics analysis. Kalyani, publisher, Ludhiana, New Delhi, India, Pp-303. 